\title{
An Intergenerational Ecological Jurisprudence: The Supreme Court of Colombia and the Rights of the Amazon Rainforest
}

\author{
Alessandro Pelizzon ${ }^{1}$ \\ Southern Cross University, Australia
}

\begin{abstract}
In 2017, 25 young Colombians, aged 15 to 25 , filed the first climate change and future generations lawsuit in Latin America (the Amazon case). Assisted by the organisation Dejusticia, the young plaintiffs filed an accion de tutela - a special mechanism under the Colombian Constitution that allows individuals to demand the protection of their fundamental rights. The plaintiffs argued that the current deforestation rates and their destructive consequences were violating their future right to a healthy environment. Remarkably, the Supreme Court of Colombia, in which the action was filed, ruled in favour of the plaintiffs, granting their petition and guaranteeing their right to enjoy a healthy environment, as well as their future rights to life, health, food and water. To enforce its judgment, the Court ordered that the Colombian Government formulate an action plan and an intergenerational pact to protect the Amazon. Most importantly, the court went beyond the grounds raised by the plaintiffs and recognised the Amazon rainforest as a subject of rights. Located within a growing network of constitutional, legislative and judicial initiatives in a growing number of jurisdictions, the Amazon case is but one example of the emergence of a novel ecological jurisprudence that is emerging around the globe. The Amazon case is particularly emblematic, as it reveals a profound ontological shift among younger generations, for whom a purely anthropocentric worldview appears to be increasingly representative of an untenable sense of alienation. The Amazon case also creates hope for a world in which an ecological jurisprudence is at the core of the current intergenerational discourse, the focus of which appears to be the global reconceptualisation of our collective self for generations to come.
\end{abstract}

Keywords: Ecological Jurisprudence; Amazon; Colombia; climate change.

\section{PART I-The Colombian Amazon Rainforest Case}

In 2017, 25 young Colombians, then aged 15 to 25 and living in 17 different Colombian municipalities, initiated the first successful climate change and future generations lawsuit in Latin America ${ }^{2}$ and, indeed, the world. ${ }^{3}$ Assisted by the organisation Dejusticia, the young plaintiffs filed a tutela action - a special action under the Colombian Constitution that allows individuals to demand the protection of their fundamental rights. In this action, the plaintiffs contended that the current deforestation rates and their destructive consequences were violating their future right to a healthy environment. ${ }^{4}$ They further submitted that

\footnotetext{
${ }^{1}$ Senior Lecturer, School of Law and Justice, Southern Cross University, Australia.

${ }^{2}$ Corte Suprema de Justicia [Supreme Court of Justice], STC4360-2018, Radicación n. 11001-22-03-000-2018-00319-01, 5 April 2018 (Amazon case).

${ }^{3}$ A previous case on climate change and future generations had already been filed by 21 young plaintiffs in the US in 2015; however, after an initial success before the Federal District Court, it was dismissed in 2020 by the $9^{\text {th }}$ Circuit Court of Appeal.

${ }^{4}$ Dejusticia, "In historic ruling."
}

This work is licensed under a Creative Commons Attribution 4.0 International Licence. As an open access journal, articles are free to use with proper attribution. ISSN: 2652-4074 (Online) 
climate change is and (more importantly) will continue to be a direct threat to their fundamental rights to life, health, food and water, which would continue to diminish due to the damage that is likely to occur and the effects of business-as-usual activities in the near future. ${ }^{5}$

The Supreme Court of Colombia delivered a remarkable judgment in an untraditional environmental damage case. The presiding judge, Justice Tolosa, ruled in the plaintiffs' favour, granting their petition and guaranteeing the right to enjoy a healthy environment and their future rights to life, health, food and water. Moreover, Justice Tolosa ordered that the Colombian Government must formulate an action plan to reach zero-net deforestation in the Amazon by 2020 and create an intergenerational pact for the future of the Amazon. More importantly, in granting the plaintiffs' petition, Justice Tolosa went beyond the grounds raised in the plaintiffs' brief by recognising the Amazon rainforest as a subject of rights. Justice Tolosa later stated, 'our community is much wider and more diverse than what we used to think. Earth does not belong to human beings. On the contrary, human beings are the ones who belong to the Earth' ${ }^{6}$

The young plaintiffs were driven by an awareness that they were the first generation to reach adulthood in peace-Colombia had reached a peace agreement three years earlier, ending decades of internal strife - and the last generation that, according to overwhelming scientific consensus, would be able to stop the most destructive and devastating consequences of climate change. The plaintiffs considered the primary drivers of greenhouse emissions in Colombia and reports that deforestation alone accounted for $36 \%$ of these emissions. In 2016, deforestation in the Colombian Amazon, one of the most biodiverse regions of the planet, increased by 44\%; in this time, 170 thousand hectares (an area equivalent to the size of Long Island) were cut down in a single year and many areas that had previously been inaccessible because of conflict were now within easy reach of loggers. ${ }^{7}$

The plaintiffs argued that they would reach adulthood between 2040 and 2070, when, according to virtually all climate change scenarios modelled on the current trends, they would be living in a country at least $1.6 \%$ warmer, whose water cycles would have been profoundly altered by deforestation, with significantly increased occurrences of floods, droughts, landslides, as well as decreased access to water and food security. Thus, despite not living in the Amazonian region themselves, the plaintiffs argued that anything that happens in the region has, and will continue to have, a direct impact upon them, and indeed everyone in Columbia and the rest of the world. The plaintiffs based their action on four legal pillars:

1) The Paris agreement to reduce greenhouse emissions, which in its preamble explicitly refers to 'intergenerational equity';

2) A multilateral agreement between Colombia, the United Kingdom (UK), Norway and Germany to stop deforestation in the Amazon;

3) The Colombian Constitutional right to a healthy environment; and

4) The National Development Plan that set a deforestation rate of less than 90,000 hectares per year.

To understand the position of future generations, the plaintiffs asked the court to take into account five principles in determining the matter: the precautionary principle; the principle of participation; the principle of the best interests of the children; the principle of intergenerational equity; and the principle of solidarity (i.e., solidarity with other humans, future generations and non-human beings). ${ }^{8}$ Finally, aware that they faced enormous difficulties in proving that the future lives of children living hundreds of kilometres away from the rainforest would be impacted in the future by actions presently being conducted there (which they needed to prove to show that they had standing to bring the case), most of the voluminous scientific evidence they presented was directly drawn from studies conducted by the government itself. ${ }^{9}$

In his judgment, Justice Tolosa reasoned that when faced with accurate and overwhelming scientific evidence, judges cannot simply ignore that evidence, but must intervene to stop the inaction of both governmental entities and private businesses. Thus, in such cases, affirmative action represented both a judicial duty and an ethical imperative. Justice Tolosa further determined that a number of environmental rights are available to all Colombian citizens as Constitutional rights and their protection does not need to be explicitly invoked by a plaintiff for them to be applied. In recognising such rights, Justice Tolosa referred to and

\footnotetext{
${ }^{5}$ Dejusticia, "In historic ruling."

${ }^{6}$ Tolosa, "Mother Earth Approach."

${ }^{7}$ Eslava, "Future Generations Fighting Climate Change."

${ }^{8}$ A detailed analysis of each principle is beyond the scope of this paper.

${ }^{9}$ Eslava, "Future Generations Fighting Climate Change."
} 
applied the principles articulated by the Constitutional Court of Colombia in the Atrato case of $2017 .{ }^{10}$ In that nuanced and detailed judgment, the Constitutional Court recognised the Atrato river as a legal subject, an entity to be represented by specifically appointed 'guardians of the river' with the equal participation of the Indigenous communities that have lived in the region since ancestral times.

Justice Tolosa explicitly referred to three principles: firstly, the principle of an 'Estado de derecho constitucional y ambiental' (a state based on a constitutional and environmental rule of law); secondly, the principle of ecological public order; and thirdly, the principle of ecological sovereignty. Justice Tolosa noted the need for a paradigmatic epistemological change, a 'Copernican revolution' regarding the category of legal subjectivity, which can no longer be limited to humans alone. To move beyond a token application of the precautionary principle, Justice Tolosa reasoned that a more ecologically aware ethical approach must be grounded in 'moral de la alteridad' (a 'morality of the other') that would be capable of encompassing not only all other humans, but also all future humans and the non-human world. ${ }^{11}$ The idea of the legal personhood of nature and of the rights of nature was thus an important symbolic and ethical responsibility (shared by all) to safeguard children, grandchildren and all of posterity. This responsibility made it necessary to declare the Amazon basin a legal subject, even though the plaintiffs had not explicitly asked the court to do so and even though the plaintiffs did not live in the Amazonian region themselves.

Justice Tolosa's judgment can be described as a 'courageous' judgment, one that, in the words of Justice Francois Kunc of the Supreme Court of New South Wales, ${ }^{12}$ displays courage as a fundamental judicial value. Further, as Justice Antonio Herman Benjamin of the High Court of Brazil observed, ${ }^{13}$ the emblematic decision demonstrates the profound need for the judiciary to meaningfully engage with legal concepts and the depth of novel legal theory, even in instances where doings so takes members of the judiciary outside their 'comfort zone'.

More importantly, this judgment highlights a shift in legal thought that has gained momentum over the past decade towards a novel 'ecological jurisprudence'. This concept will be explored and contextualised further below in Parts II and III. Specifically, Part II will trace the theoretical origin of 'ecological jurisprudence' with particular reference to the emergence of the theory known as 'Earth jurisprudence' at the beginning of the $21^{\text {st }}$ century. Part III will focus on the contextual articulation of this novel theory in a number of international jurisdictions. After providing the necessary contextual background, the article will then return to the central thesis that was introduced in this section: that is, that a radical shift in legal thinking is occurring (increasingly, it appears) in response to the demands of younger generations, whose political claims tend to be more clearly and explicitly ecologically focused. ${ }^{14}$ This article contends that the influence of the younger generations on the discourse of ecological jurisprudence is capable of engendering an atmosphere of hope and providing the necessary framework within which we, as humans, can reconceptualise our collective self in relation to the non-human world for future generations.

\section{PART II-The Rise of an Ecological Jurisprudence}

The recognition by the Supreme Court of Colombia of the Amazon basin as a legal subject forms part of a larger trend, which has been inscribed both in legal theory and legal practice over the last decade and which has grown exponentially over the last few years. Almost 50 years ago, in 1972, Professor Christopher Stone of the University of Southern California concluded one of his property law lectures with the then (and arguably, still) provocative question: 'Should trees have standing?' 15 At that time, it could have hardly been predicted that the answer to the question would, relatively soon (at least in academic terms), be in the affirmative. Despite '[originally being] greeted ... with [laughter and] uproar', ${ }^{16}$ Stone's initial thought experiment had a profound influence on the dissenting opinion of Justice Douglas in Sierra Club v Morton. ${ }^{17}$ Justice Douglas accepted Stone's proposition that, "if standing were the barrier, why not designate ... the wilderness area as the plaintiff "adversely affected", ${ }^{18}$ thus opening the legal world to the possibility of imagining the natural world as an active participant in human legal proceedings.

\footnotetext{
${ }^{10}$ Corte Constitucional [Constitutional Court], Decision T-622 10/11/2016 (Colombia) (Atrato case).

11 Tolosa, "Mother Earth Approach."

${ }^{12}$ Kunc, "Courage as a Legal Virtue",

${ }^{13}$ Benjamin, "Mother Earth Approach."

${ }^{14}$ See, for example, O’Brien, "Exploring Youth Activism;" Partridge, "From Ambivalence to Activism."

${ }^{15}$ Stone, "Should Trees Have Standing?"

${ }^{16}$ Stone, "Should Trees Have Standing?" xii.

${ }^{17}$ Sierra Club v Morton, 405 US 727 (1972).

${ }^{18}$ Stone, "Should Trees Have Standing?" xiii.
} 
Although initially dismissed, Stone's argument was well ahead of the contemporary consensus on the matter and innovative in its recognition of the interplay between an anthropogenic environmental influence and profound ecological alterations. Consequently, Stone argued that 'nature' should be removed from the category of legal things or objects and cast as a legal subject to increase the legal protection to which it was entitled. Two decades later, Stone's argument was embraced by the writings of eco-theologian and 'Earth scholar', Father Thomas Berry. ${ }^{19}$ One may wonder why, for over two decades, Stone's invitation failed to capture the legal imagination of his contemporaries and ask what, in 1972, made the environmental damages decried by the author legally invisible or at least legally irrelevant.

While it is difficult to precisely identify the origin of an idea, casting a historical eye towards a particular worldview within which law exists in a purely human sphere, ontologically separate from ecological considerations, may provide some answers. Such a worldview may be directly linked to the very idea of 'nature' that accompanied the rise of Western civilisation over the past two or three millennia. ${ }^{20}$ Greek philosophers, particularly pre-Socratic ones, were deeply concerned with the definition of 'matter' and considered the quest for such a definition somewhat coterminous with the definition of 'nature'. ${ }^{21}$ They wondered whether matter is a continuous substance capable of being expressed in multiple forms or whether it is comprised of separate and distinct components. The most notable answer still relevant to this day is arguably the one provided by Democritus, who viewed matter (or nature) as consisting of discrete, separate and independent units that he called 'atoms'. The view of matter as a collection of, ultimately, ontologically separate components became the basis of modern science. Brian Swimme and Mary Evelyn Tucker define the worldview construed upon these foundations as '[d]eterministic materialism ... a worldview that [has] three tenets: that all things in the universe [are] composed of tiny particles of matter; that these particles [are] purely material, without any degree of subjectivity, and that these particles [move] according to fixed, mathematical laws. ${ }^{22}$

Thus, it may not be coincidental that such a view of 'nature' was solidified in its modern form at the very onset of modern science with the $17^{\text {th }}$ century writings of Rene Descartes, whose famous epistemological syllogism soon became the basis for modern science's accepted ontology. Informed by Judeo-Christian medieval metaphysics, Descartes famously divided all matter between three discrete types of substances, res divina (God), res cogitans (the 'mind') and res extensa (all 'matter'). ${ }^{23}$ According to Descartes, only humans, among the totality of creation, possessed a mind and thus all other 'things' were just that, 'things', including not only all 'inanimate' objects and phenomena, but also all other non-human living beings. Cartesian philosophy, politically supported by a tradition still founded upon feudal imperialism, solidified both human exceptionalism and ontological anthropocentrism. Under this philosophy, only humans could be seen as ontological subjects and everything else was viewed as ontological objects. It thus comes as no surprise that 'for centuries scientists have attempted to explain the universe by means of physical laws expressed in mathematical equations. The universe was thought to consist of mechanisms within mechanisms'. ${ }^{24}$

Nature, thus conceived, became a mere collection of objects, something to tame and conquer, in its inherent 'alienness', for the benefit of thinking humans. As Swimme stated:

Modern industrial humans ... did not seek to commune with nature ... They sought to transform the world. ... Using these new technological powers they would create a better world, one with greater quantities of food, more efficient transportation, and faster communication. Using their new machines, they would eliminate poverty, hunger and sickness. ${ }^{25}$

We can only speculate as to whether the intentions were indeed that noble; however, it is certain that nature as something thus intended could only reach its full potential when properly 'developed' for human purposes, leading to the consequences we observe today. As Swimme and Tucker wrote, '[d]ynamized by their technology and their dreams of material progress ...

\footnotetext{
${ }^{19}$ See Berry, "The Dream of the Earth;" "The Great Work;" "The Sacred Universe."

${ }^{20}$ Some authors even suggest that such a worldview could be linked to the agricultural expansion, initiated over 35,000 years ago and culminating in the Neolithic revolution of 10,000 years ago. According to these authors, it is likely that a radical change occurred in the minds of protean sedentary farmers and villagers, whereby their surrounding environment transformed from an all-encompassing and comprehensive metaphysical and social architecture within which to flourish, to a wildland that was replaced by productive agricultural (often intended as a collection of monocultures) fields. See, for example, Harris, Cannibals and Kings; Diamond, Guns, Germs, and Steel; Tudge, Neanderthals, Bandits and Farmers. However, others argue against a linear idea of agriculture, acknowledging the plurality of agricultural practices, some of which are capable of producing sustainable lifestyles over millennia; see Pascoe, Dark Emu.

${ }^{21}$ See, among others, Russell, A History of Western Philosophy.

${ }^{22}$ Swimme, The Journey of the Universe, 103-104.

${ }^{23}$ For a good commentary on Descartes, see for example, Russell, A History of Western Philosophy.

${ }^{24}$ Swimme, The Journey of the Universe, 49.

${ }^{25}$ Swimme, The Journey of the Universe, 99-100.
} 
modern humans transformed the planet into a bundle of resources. They produced food in quantities never seen in history, and consequently populations exploded.' As a result, '[f]eeding and housing these many humans ... led to the depletion of the oceans, the degradation of the forests, and the loss of topsoil ... The paradox of unintended consequences is now becoming evident. The oceans, the rivers, the atmosphere, and the soil have all been severely degraded by our actions. ${ }^{26}$

However, this transformation did not occur in purely ontological terms. Rather, the ontological possibilities awarded by Cartesian philosophy (further articulated by Lockean individual liberalism) combined with specific legal structures to transform the world. European societies followed by the rest of the globalised world deployed legal and normative structures that allowed natural landscapes to be physically reshaped by the collective effort of humans. ${ }^{27}$ Normative structures permitted 'wild' places to be plied and shaped according to the conquering ontological ideals expressed above. Nicole Graham used the term 'lawscape' to describe the interdependence between law, property regimes and environmental ontologies. ${ }^{28}$ Due to human pervasiveness and technological invasiveness, every landscape we see (and inhabit) today is the direct result of this combination of ontological possibilities and legal structures. Thus, within the worldview described above, nature is seen as a collection of objects and more particularly, a collection of objects controlled by other subjects' property rights.

If nature is just an object of rights and if the subjects possessing such rights have absolute power over that which is the object of such rights, then the environmental damage decried by Stone in 1972 is legally invisible. Thus, Stone's question was provocative because of its profound ontological challenge, which far transcended the mere issue of extended standing. Indeed, Stone's argument opened the possibility of a shift from an anthropocentric to a biocentric or even ecocentric worldview, requiring a much more mindful approach to our interaction (as a collective species) with the rest of nature. In 1962, Rachel Carson had already issued the following warning:

The earth's vegetation is part of a web of life in which there are intimate and essential relations between plants and the earth, between plants and other plants, between plants and animals. Sometimes we have no choice but to disturb these relationships, but we should do so thoughtfully, with full awareness that what we do may have consequences remote in time and place. ${ }^{29}$

Stone's innovative proposal ${ }^{30}$ and Carson's insights ${ }^{31}$ coalesced in the writings of Father Thomas Berry, who argued that, since humans are part of an interconnected system of beings and phenomena, the wellbeing of which is foundational on the wellbeing of all its components, then the safeguarding of this system is more important than each individual member of the system, including humans. A biocentric or ecocentric perspective, inherently focused on the system as a whole, is thus preferable in long-term ecological terms to an anthropocentric one and, consequently, legal and governance systems should be developed in accordance with such perspective. As a result, Berry called for 'a jurisprudence that would provide for the legal rights of geological and biological as well as human components of the Earth community.' 32

Berry's invitation to articulate in political and legal terms this systemic approach to life (already advocated by a number of scientists $)^{33}$ was further embraced by South African lawyer Cormac Cullinan in his seminal book Wild Law. ${ }^{34}$ In his book, Cullinan defined the novel Earth jurisprudence advocated by Berry as:

\begin{abstract}
... a philosophy of law and human governance that is based on the idea that humans are only one part of a wider community of beings and that the welfare of each member of the community is dependent on the welfare of the Earth as a whole. From this perspective, human societies will only be viable and flourish if they regulate themselves as part of this wider Earth community and do so in a way that is consistent with the fundamental principles that govern how the Universe functions (the "Great Jurisprudence'). ${ }^{35}$
\end{abstract}

A full theoretical appraisal of Cullinan's usage of the term 'Great Law' or 'Great Jurisprudence' (used to describe the 'laws or principles that govern how the universe functions,') is beyond the scope of this paper; however, Cullinan's writing undoubtedly

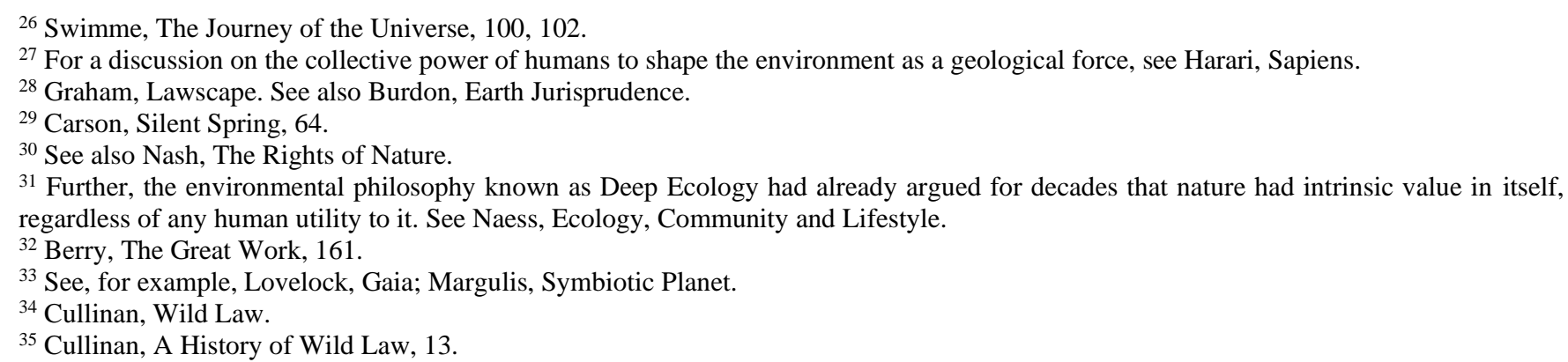


further animated the theoretical terrain from which a number of Constitutional, judicial and legislative initiatives granting nature both legal subjectivity and rights emerged. Further, this emergence of an Earth jurisprudence forms part of a larger theoretical trend that challenges an inherently reductionist and anthropocentric view of both ontology and normativity, a trend that the author of this paper previously defined as an Ecological jurisprudence. ${ }^{36}$

\section{PART III-Judicial and Legislative Precedents}

Cullinan's book Wild Law acts as a symbolic threshold between a theoretical discussion on the emerging legal subjectivity of nature and the actual implementation of the rights of nature initiatives around the world. In 2006, for the first time in recorded legal history, the Community Environmental Legal Defense Fund (CELDF) in the United States (US) included the local ecosystem as a subject of rights in a local ordinance drafted by the small community of Tamaquah Borough, in Schuylkill County, Pennsylvania. ${ }^{37}$ Since then, scores of local ordinances have been drafted by local communities in the US with CELDF's assistance, the most prominent of which include the ordinance passed unanimously by the City Council of Pittsburgh, Pennsylvania, and the more recent Lake Erie Bill of Rights, which was adopted by the residents of Toledo, Ohio. Despite being rejected by a number of courts, ${ }^{38}$ these controversial ordinances represent a profound thirst for ecological jurisprudence from (at least a section of) the US population.

The above-mentioned US examples reflect somewhat minor attempts to enshrine the rights of nature within existing legal protocols; however, in the emergence of nature's legal subjectivity, the most momentous event is undoubtedly Ecuador's recognition of nature's intrinsic rights as guaranteed in four constitutional provisions in $2008 .{ }^{39}$ Profoundly influenced by local Indigenous perspectives - as articulated by the Indigenist-based movement and the political party Pachakutik Plurinational Unity Movement ${ }^{40}$ - and with some assistance from CELDF, the Constitutional Assembly inscribed, for the first time in the world, both rights of 'Nature' (capitalised in the text) and a previously marginalised worldview (the concept of Pachamama, derived from a pan-Andean cosmology) within a Constitutional document. The Ecuadorian Constitution formed the basis for a number of judicial rights of nature decisions, the first successful of which was the Vilcabamba decision of 2011 in which the Municipality of Loja was found to be in breach of the rights of the Vilcabamba River and consequently ordered to restore and repair the damages caused to the pre-existing river bed. ${ }^{41}$

Shortly thereafter in 2010, Bolivia's then Aymara President Evo Morales convened a World People's Conference on Climate Change and the Rights of Mother Earth in Tiquipaya, just outside Cochabamba, in direct response to the perceived failure of Conference of the Parties (COP) negotiations in Copenhagen at the end of 2009. More than 30,000 delegates flooded the small Andean city and, with the input of Cullinan, CELDF and a host of Ecuadorian representatives, drafted the Universal Declaration of the Rights of Mother Earth, ${ }^{42}$ a central document for the entire rights of Nature movement. Subsequently, in 2010 and 2011 , Bolivia passed two pieces of legislation that directly recognise the rights of 'Mother Earth'. ${ }^{43}$

The Latin-American examples were soon followed by a host of initiatives around the world. In 2009, the United Nations General Assembly proclaimed 22 April as International Mother Earth Day and, in so doing, launched the Harmony with Nature programme. ${ }^{44}$ In the UK, the European Citizen's Initiative for the Rights of Nature was launched in 2013 and the Green Party of England and Wales adopted a rights of nature policy platform in 2016. Mexico City adopted legislation to 'recognize and regulate the broader protection of the rights of nature formed by all its ecosystems and species as a collective entity subject to

\footnotetext{
${ }^{36}$ The term, initially coined in personal discussions with Cormac Cullinan to transcend the planetary boundaries implicit in the 'earth' portion of an Earth jurisprudence, was first used in early 2012. It was also used to encompass a host of arguments and theoretical perspectives not explicitly or expressly aligned with the Earth jurisprudence movement, including those embodied by the legal orders of many Indigenous peoples around the world. See Pelizzon, "Earth laws."

${ }^{37}$ Community Environmental Legal Defense Fund, "Timeline."

${ }^{38}$ For a good overview of the controversial nature of these ordinances, see, Fox, "Home Rule."

${ }^{39}$ Constitución del Estado Plurinacional de Bolivia 2008 [Constitution of the Plurinational State of Bolivia 2008].

${ }^{40}$ Mijeski, Pachakutik.

${ }^{41}$ Wheeler et al. $v$ Director de la Procuraduria General del Estado, Judgment 11121-2011-0010 (31 March 2011) (Corte Provincial de Justicia de Loja [Provincial Court of Justice of Loja]) (Vilcabamba case). An overview of additional cases is provided by Kauffman, "Testing Ecuador's Rights of Nature."

${ }^{42}$ Universal Declaration on the Rights of Mother Earth.

${ }^{43}$ Ley De Derechos De La Madre Tierra [Mother Earth Rights Law], Ley N 71, 21 December 2010 (Bolivia), and Ley Marco De La Madre Tierra y Desarrollo Integral Para Vivir Bien (Law of Mother Earth and Integral Development for Living Well], Ley N 300,15 October 2012 (Bolivia).

${ }^{44}$ United Nations General Assembly, GA RES 63/278, 63 ${ }^{\text {rd }}$ session, Agenda Item 49(d), UN Doc A/RES/63/278 (22 April 2009$)$.
} 
rights' in 2017 and the municipalities of Bonito and Paudalho in the Brazilian State of Pernambuco enacted the rights of nature laws in 2017 and 2018, respectively. In 2019, Uganda passed the National Environmental Act of 2019 in which (in language similar to that used in the Ecuadorian Constitution) nature is recognised as having 'the right to exist, persist, maintain and regenerate its vital cycles, structure, functions and its processes in evolution. ${ }^{25}$

Visibly and vocally present since the onset of the movement, Indigenous voices have become even more central over the last five years. As the result of the negotiating efforts of two distinct Maori Iwis, New Zealand has recognised the legal personhood of two geographical features (which are seen as far more than mere geographical entities by each Maori Iwi living within their proximity): the Te Urewera forest in 2014 and the Whanganui River in $2017 .{ }^{46}$ The latter is of particular significance as the first full articulation of nature (or, more correctly, a portion thereof) as a legal person and has been profoundly influential in a number of instances, not the least because it was a direct precursor to the Colombian decision that provided the initial focus of the present paper.

In the US, the Ho-Chunk Nation voted for a rights of nature tribal Constitutional amendment in 2016, the Ponca Nation of Oklahoma recognised the same in 2018, the White Earth band of the Chippewa Nation recognised the rights of manoomin (wild rice) in 2019 and in that same year, the Yurok tribe recognised the legal rights of the Klamath River. ${ }^{47}$ Despite some initial hesitancy, Indigenous peoples in the US now appear to be strategically adopting the rights of nature as a legal tool that is both understandable by the colonial legal system and capable of conveying some of the (otherwise excluded) metaphysical complexities of traditional worldviews. ${ }^{48}$

In 2017, directly influenced by the Te Awa Tupua (Whanganui Claims Settlement) Act of New Zealand, the High Court of Uttarakhand in India granted legal personhood to the Ganges and Yamuna rivers and their tributaries, ${ }^{49}$ glaciers, lakes, air, meadows, dales, jungles, forests, wetlands, grasslands, springs and waterfalls. ${ }^{50}$ That same year, the Australian State of Victoria passed the Yarra River Protection (Wilip-gin Birrarung murron) Act 2017 (Vic), which declared the Yarra River (or Birrarung in the Woi-wurrung language) 'one living and integrated natural entity' ${ }^{51}$ and the NGO Deep Green Resistance commenced (since then unsuccessful) litigation in the name of the Colorado River Ecosystem in the US District Court in Denver, Colorado in which it sought to have the entire ecosystem declared a juridical person capable of possessing rights. More recently, in 2019, the High Court of Bangladesh also recognised the legal rights of rivers; however, it is the sophisticated earlier Colombian judgment on the Atrato River ${ }^{52}$ that is relevant as the direct precedent of the Amazon decision. In addition to influencing, shortly thereafter, the Amazon basin decision, the Atrato case forms the basis for a host of similar decisions in 2019, such as the Coello, Combeima and Cocora Rivers case (decided in the Regional Court of Tolima), the Cauca River case (decided in the Superior Court of Medellín), the Plata River case and the Páramo in Pisba (a high Andean ecosystem) case (decided in the Administrative Court of Boyacá). ${ }^{53}$

In the Atrato case, the Colombian Constitution was interpreted by the Colombian Constitutional Court to construe the Atrato River as a subject of legal rights. The case was initiated by a group of plaintiffs who launched an accion de amparo ${ }^{54}$ against both the local and national institutions for failing to protect a number of constitutionally enshrined fundamental rights to stop intensive, large scale and largely illegal mining and logging practices. The plaintiffs argued that these practices were having highly negative and irreversible effects on local ecosystems that were threatening the very survival of the river itself and in turn, impacting the fundamental rights of local Indigenous and afro-Colombian communities. Despite initially rejecting this argument, the Constitutional Court of Colombia accepted the action (directed to the protection of the constitutionally enshrined

\footnotetext{
${ }^{45}$ Community Environmental Legal Defense Fund, "Timeline."

${ }^{46}$ Te Urewera Act 2014 (New Zealand) and Te Awa Tupua (Whanganui Claims Settlement) Act 2017 (New Zealand). New Zealand is currently negotiating the same recognition for a third geographical feature of the North island, Mt. Taranaki.

${ }^{47}$ Community Environmental Legal Defense Fund, "Timeline."

48 The unique features of US Tribal Constitutional Law, which protects Indigenous sovereign tribes from State interference, may be particularly significant in contextualizing this particular US development.

${ }^{49}$ Mohd. Salim v State of Uttarakhand \& Others, Uttarakhand H.C. 126 (India) (20 March 2017) (High Court of Uttarakhand, India)

(Ganges and Yamuna case). It is important to note that the Supreme Court of India granted a stay of the order and is yet to rule on the matter.

${ }^{50}$ Lalit Miglani v State of Uttarakhand \& Others (30 March 2017) MCC 139/2017 (30 March 2017) (India) (Glaciers case).

${ }^{51}$ Yarra River Protection (Wilip-gin Birrarung murron) Act 2017 (Vic), 1(a).

${ }^{52}$ Corte Constitucional [Constitutional Court], Decision T-622 10/11/2016 (Colombia).

${ }^{53}$ Herrera-Santoyo, "The Rights of Nature."

${ }^{54}$ An accion de amparo, or accion de tutela, is an action guaranteed by section 86 of the Colombian Constitution for the protection of constitutional rights.
} 
rights to life, health, water, food security, to a healthy environment, to culture, to physical, cultural and spiritual survival and to the protection of the territory for the local ethnic communities), concluding that the right to a healthy environment directly affects a host of other rights that have been acknowledged as fundamental by both the Constitution and the jurisprudence of the Constitutional Court.

The Court further stated that the Colombian Constitution is informed by the concept of the social rule of law (Estado Social de Derecho $)^{55}$ and by a jurisprudential tradition that has articulated a so-called Ecological Constitution for well over two decades. The Court reasoned that the realisation of a social rule of law is made possible by the protection of nature as a matter of primary collective interest and is superior to other fundamental rights (and is also guaranteed by over 30 constitutional provisions). Consequently, the protection of the environment as the primary avenue for realising a social rule of law is inherently articulated through a series of biocultural rights, ${ }^{56}$ the central premise of which is a relationship of profound unity between nature and the human species. Thus, 'biological protection and cultural rights are seen not as separate, but as profoundly intertwined and ultimately inseparable'. ${ }^{57}$

The Court supported its nuanced argument by expressly acknowledging the parallel lines of thinking embodied in the 2008 Ecuadorian Constitution, the 2009 Bolivian Constitution, the Ecuadorian Vilcabamba case and the Te Awa Tupua Act in New Zealand. The Court's decision is not directly stated in terms of an ecological jurisprudence; however, the theoretical relevance of an ecological jurisprudence is undeniable. Indeed, the Court explicitly reflected upon a clear ontological spectrum and explicitly asserted, against a classical anthropocentric perspective, that whereby the environment is purely instrumental to human survival and even beyond a biocentric perspective, whereby Nature is to be protected to prevent an environmental catastrophe, an ecocentric perspective is to be preferred, which holds that 'the earth does not belong to humans, but rather it is humans who belong to the earth' ${ }^{58}$ The consequence of this perspective is that nature must be embraced as a legal subject and protected by the State through its legal representatives. Commentary on the case recognises that 'the environmental patrimony is not exclusive to a geographically, jurisdictionally and temporally bounded human community, but rather belongs to humanity in general, including all future generations'. ${ }^{5}$

As discussed above in Part II, the Atrato case, with its visionary philosophy upon which the Amazon case was ultimately based, thus inscribed the judicial trajectory of Colombian jurisprudence entirely within the emergence of an ecological jurisprudence. Equally importantly, the case also revealed the clear emergence of an intergenerational shift, whereby younger generations, immediately faced with the threat of profound environmental degradation, appear to be more inclined to embrace ecological jurisprudence.

\section{PART IV—The Rise of an Intergenerational Ecological Awareness}

Gabriela Eslava, both one of the plaintiffs and one of the lawyers for the Amazon case, stated that '[w]e wanted to demonstrate that climate change is a human rights problem, and that it has a face: the face of those who are young today' ${ }^{60}$ Eslava's words aptly echo the views of many youth who have protested and marched around the world in the past two years. Many of these youths have been inspired by the words and actions of the young Swedish activist Greta Thunberg. At the commencement of the COP24, Thunberg, age 15, stated:

We have not come here to beg the world leaders to care for our future. They have ignored us in the past and they will ignore us again. We have come here to let them know that change is coming whether they like it or not. The people will rise to the challenge. And since our leaders are behaving like children, we will have to take the responsibility they should have taken long ago. ${ }^{61}$

It is difficult, in hearing Thunberg's words, not to be reminded of the now prophetic description of Doris Lessing in her book Shikasta of 'youth armies' (i.e., cohorts of organised young people who transition an environmentally degraded society into a more sustainable and serene future). ${ }^{62}$ Since late 2018, children around the world have been 'taking cues from Greta, the girl

\footnotetext{
${ }^{55}$ Derived from the German articulation of a sozialrechtsstaat.

${ }^{56}$ Bavikatte, "Community Stewardship."

${ }^{57}$ Clark, "Can You Hear the Rivers Sing?", 787.

${ }^{58}$ Corte Constitucional [Constitutional Court], Decision T-622 10/11/2016 (Colombia) (Atrato case), 5.9.

${ }^{59}$ Clark, "Can You Hear."

${ }^{60}$ Eslava, "Future Generations Fighting Climate Change."

${ }^{61}$ Quelly, "We Have Not Come Here."

${ }^{62}$ Lessing, Shikasta.
} 
who takes social cues from no one, and ... organizing student strikes of their own. ${ }^{63}$ Since 2018, these 'school strikes for the climate' have increased exponentially both in size and number and attest to a very clear sense of urgency on the part of the younger generations, as represented by some of their placards quoting some of Thunberg's 'most piercing words: I want you to panic, our house is on fire. ${ }^{64}$

Ludvig Beckman argues that, "[g]iven the capacity of the living generation to reshape and destroy the future we are undoubtedly in possession of "superior power" in relation to future people. ${ }^{65}$ Notwithstanding Beckman's conclusion that current anthropogenic threats to the environment do not constitute a form of 'intergenerational domination', the uneven relationship of power is clearly at the forefront of the youth marches that have swept the planet of the past 18 months. Given the timeliness of the political and regulatory decisions that need to be made within a short timeframe, as suggested by virtually all Intergovernmental Panel on Climate Change reports, ${ }^{66}$ many of the young claimants are repeating the urgent pleas uttered by Thunberg in a number of international fora. As Naomi Klein suggests, " $[\mathrm{t}]$ he clarity of Greta's voice gave validation to the raw terror so many of us have been suppressing and compartmentalizing about what it means to be alive amid the sixth great extinction and surrounded by scientific warnings that we are flat out of time. ${ }^{97}$

Thus, it is unsurprising that the same younger generations are strong adopters and advocates of ecological jurisprudence. In a personal interview, Hana Begovic, the young organiser of the Global Alliance for the Rights of Nature, suggested that the articulation of nature as a legal subject of rights is the necessary response to the sense of disconnection that, albeit based on a long ontological lineage, has now become untenable for many among the younger generations. ${ }^{68}$ Anthropocentrism has thus become a primer for a sense of alienation, particularly to younger minds. Such a sensibility did not escape the court in the Amazon case, as Paola Villavicencio Calzadilla notes:

The Court admits that the consciousness of the compulsory reorientation of our behaviour and of the recognition of the intrinsic value of nature is gradually being created. Thus, a new 'ecocentric-anthropogenic' ideology has emerged, which moves away from the purely anthropocentric and utilitarian perspective and places human beings at the same level as nature with the aim to 'avoid the arrogant, dismissive and irresponsible treatment of nature and her components, only to fulfil materialistic purposes without respect for their protection or conservation'. ${ }^{69}$

Many unanswered questions remain in relation to the emerging attempt to construe nature as a legal subject within human legal systems. ${ }^{70}$ The dichotomy of the human/non-human is somewhat transcended by a legal discourse that casts natural features as legal persons; however, issues of agency and representation remain. Who speaks for a natural feature, such as the Amazon basin? In the case of the Atrato River, specific 'guardians of the rivers' were appointed by the Constitutional Court in the judgment itself. More importantly, are these representatives to act on the basis of pre-established rights and interests attributed to the natural feature they represent or are they to be instructed (so to speak) by the natural features themselves? In the latter case, beyond offering a profound ontological transformation, the emergence of ecological jurisprudence entails an even more profound epistemological challenge, one in which the normative agency of nature must be re-conceptualised. ${ }^{71}$

Notwithstanding the many unanswered (and, to many, exciting) questions entailed by the emergence of ecological jurisprudence, it is undeniable that such questions have captured the minds of the younger generations. Eslava stated that to her (and, to her knowledge, to many of her peers both within and outside the legal profession), the idea of nature as both an ontological and a legal subject (indeed as both a collection of living entities and a collective living entity in its own right) is far from farfetched or preposterous. ${ }^{72}$ Her words are mirrored by the exponential growth of academic literature, particularly on the part of younger academics, on the issue over the past decade.

\footnotetext{
${ }^{63}$ Klein, On Fire, 13.

${ }^{64}$ Klein, On Fire.

${ }^{65}$ Beckman, "Power and Future People's Freedom," 290.

${ }^{66}$ Intergovernmental Panel on Climate Change, "Reports."

${ }^{67}$ Klein, On Fire, 13.

${ }^{68}$ Begovic, "Interview with Alessandro Pelizzon."

${ }^{69}$ Villavicencio Calzadilla, "A Paradigm Shift," 7-8.

${ }^{70}$ See Schillmoller, "Mapping the Terrain;" Pelizzon, "Beyond Anthropocentrism and Back Again.”

${ }^{71}$ In so doing, ecological jurisprudence raises challenging questions of inter-normativity: Is it ever possible for nature to enter what appears (at least under the Western legal tradition) to be a purely human sphere, that of the normative? See, contra, Glenn, Legal Traditions of the World.

72 Eslava Bejarano, "Interview with Alessandro Pelizzon."
} 
Narratives of environmental collapse currently dominate both the political and fictional landscape. However, it is incorrect to describe natural events as natural disasters, even when their occurrence is only indirectly caused by human contributory factors; rather, the normativity of their description as 'disasters' should be applied to humans. Given the contributory apportion of human activities today, all devastating natural events are much better described as human disasters. Due to the inevitable tensions that arise between fear (couched in the language of environmental collapse) and hope (symbolised by the current reconceptualisation of nature, both ontologically and normatively, as a legal living entity), the Amazon case is emblematic, as it offers hope for a future in which the emergence of ecological jurisprudence is at the core of the current intergenerational discourse, the focus of which appears to be the global reconceptualisation of our collective self for future generations. Perhaps, what these generations may show us is that it may be preposterous to think that nature can remain legally silent, invisible or irrelevant today.

\section{Bibliography}

Bavikatte, Kabir and Tom Bennett. “Community Stewardship: The Foundation of Biocultural Rights.” Journal of Human Rights and Environment, no 6 (2015): 7-29. https://doi.org/10.4337/jhre.2015.01.01

Beckman, Ludvig. "Power and Future People's Freedom: Intergenerational Domination, Climate Change, and Constitutionalism.” Journal of Political Power, no 9(2) (2016): 96-119. https://doi.org/10.1080/2158379X.2016.1191159

Begovic, Hana. "Interview with Alessandro Pelizzon.” Zoom Interview, 31 January 2019.

Benjamin, Antonio Herman. "Mother Earth Approach in the Implementation of Education and Climate Change." Speech, Ninth Interactive Dialogue of the General Assembly on Harmony with Nature, United Nations General Assembly, 22 April 2019. The transcript can be found at http://files.harmonywithnatureun.org/uploads/upload822.pdf

Berry, Thomas. The Dream of the Earth. San Francisco, Sierra Club Books, 1988.

Berry, Thomas. The Great Work. New York, Random House, 1999.

Berry, Thomas. The Sacred Universe. New York, Columbia University Press, 2009.

Burdon, Peter. Earth Jurisprudence: Private Property and the Environment. Oxon, Routledge, 2015.

Carson, Rachel. Silent Spring. New York, Houghton Mifflin, 1962.

Community Environmental Legal Defense Fund. “Timeline.” https://celdf.org/advancing-community-rights/rights-ofnature/rights-nature-timeline/

Clark, Cristy, Ourania Emmanouil, John Page and Alessandro Pelizzon. "Can You Hear the Rivers Sing? Legal Personhood, Ontology and the Nitty Gritty of Governance.” Ecology Law Quarterly, no 45 (2019): 787-844.

Cullinan, Cormac. Wild Law. Foxhole, Chelsea Green, 2011 ( $2^{\text {nd }}$ ed).

Cullinan, Cormac. “A History of Wild Law” (pp. 12-23). In Exploring Wild Law, edited by Peter Burdon. Kent Town, Wakefield, 2011.

Dejusticia. "In Historic Ruling, Colombian Court Protects Youth Suing the National Government For Failing To Curb Deforestation." https://www.dejusticia.org/en/en-fallo-historico-corte-suprema-concede-tutela-de-cambio-climatico-ygeneraciones-futuras/

Diamond, Jared. Guns, Germs, and Steel. Norton and Company, 2005 (first published 1997).

Eslava Bejarano, Gabriela. "Future Generations Fighting Climate Change: The Colombian Case." Speech, Ninth Interactive Dialogue of the General Assembly on Harmony with Nature, United Nations General Assembly. 22 April 2019. The transcript can be found at http://files.harmonywithnatureun.org/uploads/upload796.pdf

Eslava Bejarano, Gabriela. "Interview with Alessandro Pelizzon.” United Nations General Assembly, 22 April 2019.

Fox, Sarah J. "Home Rule in an Era of Local Environmental Innovation." IPR Papers \& Reports, no 2 (2017): $207-263$. https://scholarship.law.georgetown.edu/ipr_papers/2

Glenn, Patrick. Legal Traditions of the World. Oxford, Oxford University Press, 2014 (5 $5^{\text {th }}$ ed).

Graham, Nicole. Lawscape. Oxon, Routledge, 2011.

Harari, Yuval Noah. Sapiens: A Brief History of Humankind. London, Harper, 2014.

Harris, Marvin. Cannibals and Kings. New York, Vintage, 1991 (first published 1977).

Herrera-Santoyo. Hector. "The Rights of Nature (Rivers) and Constitutional Actions in Colombia." https://gnhre.org/2019/07/08/the-rights-of-nature-rivers-and-constitutional-actions-in-colombia/

Intergovernmental Panel on Climate Change. "Reports". https://www.ipcc.ch/reports/

Kauffman, Craig and Pamela Martin. "Testing Ecuador's Rights of Nature: Why Some Lawsuits Succeed and Others Fail." Speech, International Studies Association Annual Convention, Atlanta, USA, 18 March 2016.

Klein, Naomi. On Fire: The Burning Case for a Green New Deal. London, Penguin, 2019. 
Kunc, François. “Courage as a Legal Virtue.” Inaugural Andrew Rogers Lecture in Private Law and Legal Practice, Lismore, Australia, 5 May 2019.

Lessing, Doris. Shikasta. Capetwon, Jonathan Cape, 1979.

Lovelock, James. Gaia. Oxford, Oxford University Press, 1979.

Margulis, Lynn. Symbiotic Planet: A New Look at Evolution. New York, Weidenfeld \& Nicolson, 1998.

Mijeski, Kenneth and Scott Beck. Pachakutik and the Rise and Decline of the Ecuadorian Indigenous Movement. University of Ohio Press, 2011.

Naess, Arne. Ecology, Community and Lifestyle. London, Cambridge University Press, 1989.

Nash, Roderick. The Rights of Nature. Madison, The University of Wisconsin Press, 1989.

O’Brien, Karen, Elin Selboe and Bronwyn M Hayward. "Exploring Youth Activism on Climate Change: Dutiful, Disruptive, and Dangerous Dissent." Ecology and Society, no 23(3) (2018): 42. https://doi.org/10.5751/ES-10287-230342

Partridge, Emma. "From Ambivalence to Activism: Young People's Environmental Views and Actions." Youth Studies Australia, no 27(2) (2008): 18-25.

Pascoe, Bruce. Dark Emu. Sydney, Magabala, 2014.

Pelizzon, Alessandro. "Earth Laws, Rights of Nature and Legal Pluralism" (pp. 176-189). In Wild Law-In Practice, edited by Michelle Maloney and Peter Burdon. Oxon, Routledge, 2014.

Pelizzon, Alessandro and Aidan Ricketts. "Beyond Anthropocentrism and Back Again: From Ontological to Normative Anthropocentrism" Australasian Journal of Natural Resources Law and Policy, no 18(2) (2015): 105-125.

Quelly, Jon. "We Have Not Come Here to Beg World Leaders to Care, 15-Year-Old Greta Thunberg Tells COP24, We Have Come to Let Them Know Change Is Coming." https://www.commondreams.org/news/2018/12/04/we-have-not-comehere-beg-world-leaders-care-15-year-old-greta-thunberg-tells-cop24

Russell, Bertrand. A History of Western Philosophy. New York, Simon and Schuster, 1945.

Schillmoller, Anne and Alessandro Pelizzon. "Mapping the Terrain of Earth Jurisprudence: Landscape, Thresholds and Horizons" Barry Environmental and Earth Law Journal, no 3(1) (2013): 3-32.

Stone, Christopher. "Should Trees Have Standing? Towards Legal Rights for Natural Objects." California Law Review, no 45 (1972): 450-501.

Stone, Christopher. Should Trees Have Standing? Oxford, Oxford University Press, 2010 ( $3^{\text {rd }}$ ed).

Swimme, Brian and Mary Evelyn Tucker. The Journey of the Universe. New Haven, Yale University Press, 2011.

Tolosa, Luis Armando. "Mother Earth Approach in the Implementation of Education and Climate Change." Speech, Ninth Interactive Dialogue of the General Assembly on Harmony with Nature, United Nations General Assembly, 22 April 2019. The transcript can be found at http://files.harmonywithnatureun.org/uploads/upload804.pdf

Tudge, Colin. Neanderthals, Bandits and Farmers. Weidenfeld and Nicolson, 1998.

Villavicencio Calzadilla, Paola. "A Paradigm Shift in Courts' View on Nature: The Atrato River and Amazon Basin Cases in Colombia.” Law, Environment and Development Journal, no 15(0) (2019).

\section{Primary Legal Material}

\section{Cases}

Corte Constitucional [Constitutional Court], Decision T-622 10/11/2016 (Colombia) (Atrato case)

Corte Suprema de Justicia [Supreme Court of Justice], STC4360-2018, Radicación n. 11001-22-03-000-2018-00319-01, April 5, 2018 (Amazon case). English translation. http://blogs2.law.columbia.edu/climate-change-litigation/wpcontent/uploads/sites/16/non-us-case-documents/2018/20180405 11001-22-03-000-2018-00319-00_decision-1.pdf

Lalit Miglani v State of Uttarakhand \& Others (March 30 2017) MCC 139/2017 (30 March 2017) (India) (Glaciers case)

Mohd. Salim v State of Uttarakhand \& Others, Uttarakhand H.C. 126 (India) (20 March 2017) (High Court of Uttarakhand, India) (Ganges and Yamuna case)

Sierra Club v Morton, 405 U.S. 727 (1972)

Wheeler et al. v Director de la Procuraduria General del Estado, Judgment 11121-2011-0010 (31 March 2011) (Corte Provincial de Justicia de Loja [Provincial Court of Justice of Loja]) (Vilcabamba case)

\section{Legislation}

Constitución del Estado Plurinacional de Bolivia 2008 [Constitution of the Plurinational State of Bolivia 2008]

Ley De Derechos De La Madre Tierra [Mother Earth Rights Law], Ley N 71, 21 December 2010 (Bolivia)

Ley Marco De La Madre Tierra y Desarrollo Integral Para Vivir Bien (Law of Mother Earth and Integral Development for Living Well], Ley N 300, 15 October 2012 (Bolivia)

Te Urewera Act 2014 (New Zealand) 
Te Awa Tupua (Whanganui Claims Settlement) Act 2017 (New Zealand)

United Nations General Assembly, GA RES 63/278, 63 ${ }^{\text {rd }}$ session, Agenda Item 49(d), UN Doc A/RES/63/278 (22 Apr 2009) Yarra River Protection (Wilip-gin Birrarung murron) Act 2017 (Vic), 1(a). It is important to note that the Supreme Court of India granted a stay of the order and is yet to rule on the matter. 